\title{
A Biogeochemical Study of Heavy Metal Leaching from Coal Fly Ash Disposed in Yeongdong Coal-Fired Power Plant
}

\author{
Duk-Ho Chung, Kyu-Seong Cho $^{2}$, and Kyeong-Jin Park ${ }^{2, *}$ \\ ${ }^{1}$ Science Education Institute for the Giffed, Chonbuk National University, Jeonbuk 561-756, Korea \\ ${ }^{2}$ Division of Science Education, Chonbuk National University, Jeonbuk 561-756, Korea

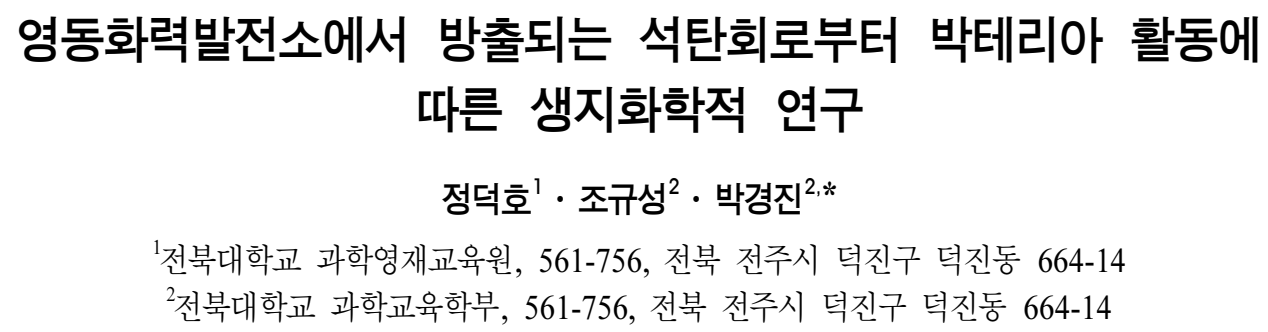

Abstract: Fly ashes derived from coal fired power plants have unique chemical and mineralogical characteristics. The objective of this research was to study how indigenous bacteria affected heavy metal leaching in fly ash slurry during the fly ash-seawater interactions in the ash pond located in Yeongdong seashore, Korea. The in-situ $\mathrm{pH}$ of ash pond seawater was 6.3-8.5. For this study, three sites of the ash pond were chosen to collect a sample of fly ash slurry. Three samples that had a mix of fly ash $(0.4 \mathrm{~L})$ and seawater $(1.6 \mathrm{~L})$ were collected at each site. First sample was autoclaved $\left(120^{\circ} \mathrm{C}\right.$, $2.5 \mathrm{~atm}$ ), second one was inoculated with glucose to stimulate the microbial activity, and the last sample was kept in the natural condition. Compared with other samples including autoclaved and natural samples, the glucose added sample showed sharp increase in its alkalinity after 15 days, cation concentration change such as $\mathrm{Ca}, \mathrm{Mg}$, and $\mathrm{K}$ seemed to increase in early stage, and then decrease 15 days later in slurry solution of glucose added sample, and a possibly considerable decrease in $\mathrm{SO}_{4}^{2-}$ in the fly ash slurry samples when glucose was added to stimulate the microbial activity. Geochemical data of this study is likely to be related to the activity of bacteria at the ash pond. The result may be used to understand about the characteristic of bacteria.

Keywords: fly ash, heavy metals, biogeochemistry, microbial leaching

요 약: 석탄회는 독특한 화학조성과 광물학적 특징을 가지고 있다. 본 연구는 해안가에 위치한 영동화력발전소의 매립 호수에서 배출되는 석탄회와 주변 해수와의 반응에서 토착 미생물이 중금속 용출에 어떤 영향을 미치는지를 알아보았 다. 매립 호수의 $\mathrm{pH}$ 는 6.3-8.5로 나타났다. 본 연구를 위해 매립 호수의 세 지점을 선정하여 각 지점에서 석탄회 $(0.4$ $\mathrm{L})$ 와 해수 $(1.6 \mathrm{~L})$ 가 혼합된 세 개의 시료를 채취하였다. 채취한 시료는 각각 $120^{\circ} \mathrm{C}, 2.5$ 기압 환경하에서 멸균 처리하고, 미생물의 활동을 촉진하기 위해 글루코스를 첨가하여 배양하였으며, 나머지 하나는 자연 상태로 60 일 동안 보관하면서 박테리아의 활동에 따른 지화학적 변화과정을 살펴보았다. 다른 시료와 비교하여 글루코스를 첨가한 시료에서 15 일 후 에 알카리도가 크게 증가하였으며, $\mathrm{Mg}, \mathrm{Ca}, \mathrm{K}$ 와 같은 양이온은 글루코스를 넣은 시료에서 초기에 증가하다가 15 일 이 후 감소하였다. $\mathrm{SO}_{4}{ }^{2-}$ 는 글루코스를 첨가한 시료에서 크게 감소하였다. 이러한 지화학적 결과는 매립 호수에 서식하는 박테리아의 활동성과 관련이 있다. 이러한 결과는 석탄회 내에 서식하는 박테리아의 특성을 이해하기 위한 기초자료로 서 활용될 수 있을 것으로 판단된다.

주요어: 석탄회, 중금속, 생지화학, 미생물학적 용출

*Corresponding author: ramsespark@jbnu.ac.kr

Tel: 82-63-270-2801

Fax: 82-63-270-2802 


\section{Introduction}

Because of the limitations of condition for waterpower generation, the safety concerns of nuclear energy generation, and the high cost for thermal power generation using oil or gas, power generation is partially dependent on coal in Korea. However, because coal has a lot of inorganic matter, coal leaves ashes about 10 to 40 wt.\% during coal combustion (Han et al., 2001). About $4.4 \mathrm{Mt}$ of fly ashes are produced annually from the combustion of coal in power plants in Korea (Lee et al., 2001). And it is produced annually worldwide about 550 Mt (Reijnders, 2005). While the power plants were built inside inland in foreign countries, they were constructed at the seashore in Korea because of convenience of getting cooling water. Thus, most of fly ashes were vulnerable to dispose into the ash ponds with seawater for a long time (Kim et al., 2002).

Coal-derived fly ashes have unique chemistry and mineralogical characteristics depending on the kind of coal and the condition of combustion (Gay and Davis, 1987). Because coal contains significant quantities of various trace elements, trace elements are enriched on the surface of the ash particle due to evaporation and condensation during combustion of coal. Especially, lots of heavy metals such as $\mathrm{V}, \mathrm{Cr}, \mathrm{Mn}, \mathrm{Co}, \mathrm{Ni}, \mathrm{Zn}$, and $\mathrm{Cu}$ are contained in Fe-oxide minerals within fly ash, so it should be considered in leaching environments (Hansen and Fisher, 1980; Lee et al., 1997). Also it is not good to use coal fly ashes thoughtlessly since it contains a variety of heavy metals (Yoon et al., 1995). Besides, we need to understand with accuracy the mobilization of heavy metals since it has a high possibility of soil, underwater, and ocean pollution around ash pond.

It has been known that physicochemical factors and microbial activities play an important role in reaction between subsurface media and fly ash (Nickson et al., 2000; Roh et al., 2001; Roh et al., 2003b). Microbial activity has numerous implications in the mobilization of heavy metals and radionuclide as well as the cycles of carbon in the natural environments. Microbes use contaminants such as $\mathrm{Cr}(\mathrm{VI})$ as a source of energy for their respiration as well as they precipitate them by biogeochemical processes in subsurface environments (White et al., 1997). There are various microbes having different characteristics and it shows various activities according to living conditions (Cho et al., 2007). So to provide a better understanding of the environmental impact of fly ash disposal, various laboratory tests have performed the immobilization of toxic metals and the characterization of leaching behaviors of ash by the indigenous microbes (Roh et al., 2003a). Several researchers had performed the research on the metal leaching from coal ash in Korea (Kim et al., 2002). However, research on the roles of microbes in fly ash disposal site has not been rather limited.

The objective of this study was to investigate whether it is possible or not to sequester carbon dioxide known as the material of global warming using fly ash originated the indigenous microbes in ash pond. And it is to check it up whether indigenous microbes facilitate the leaching of the heavy metals or not and to find out the biogeochemical roles of indigenous microbes in a reaction between seawater and fly ash in the ash pond.

\section{Materials and Methods}

\section{Study area or sampling}

The coal fly ashes were sampled from Yeongdong Coal-Fired Power Plant (January, 2006) in Korea. Yeongdong (YD) Coal-Fired Power Plant locates in Kangryeung, Kangwondo ( $\left.128^{\circ} 58^{\prime} \mathrm{E}, 37^{\circ} 44^{\prime} \mathrm{N}\right)$. Dried fly ashes were collected at the silo of the power plant. Three sites were chosen at the ash pond for the sampling of fly ash slurry. Temperature, $\mathrm{pH}$, and dissolved oxygen (DO) were measured at the sampling sites to check chemical condition of ash pond. And three samples were collected and stored in pre-clean glass bottles that had been rinsed with nitric acid in order to remove all heavy metal and organic residues. All sample, mixtures of fly ash $(0.4 \mathrm{~L})$ and seawater $(1.6 \mathrm{~L})$, were collected in 2-liter screw-cap bottle at each sites.

\section{Experimental design}

One of the samples collected from each site was autoclaved $\left(120^{\circ} \mathrm{C}, 2.5 \mathrm{~atm}\right)$ for 15 minutes. One of the 


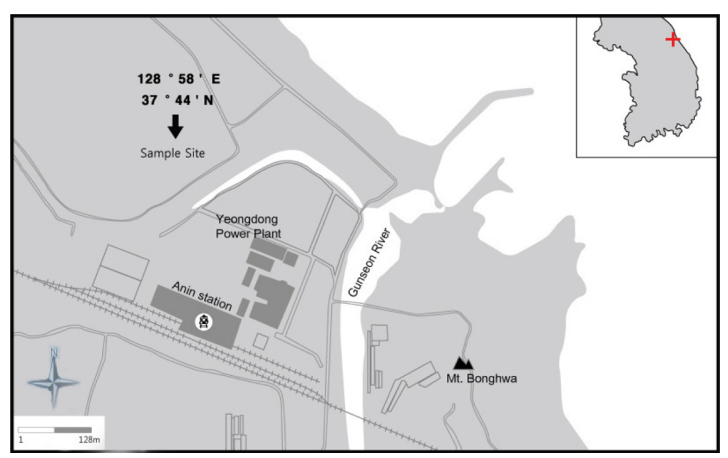

Fig. 1. Location map of Yeongdong Coal-Fired Power Plant.

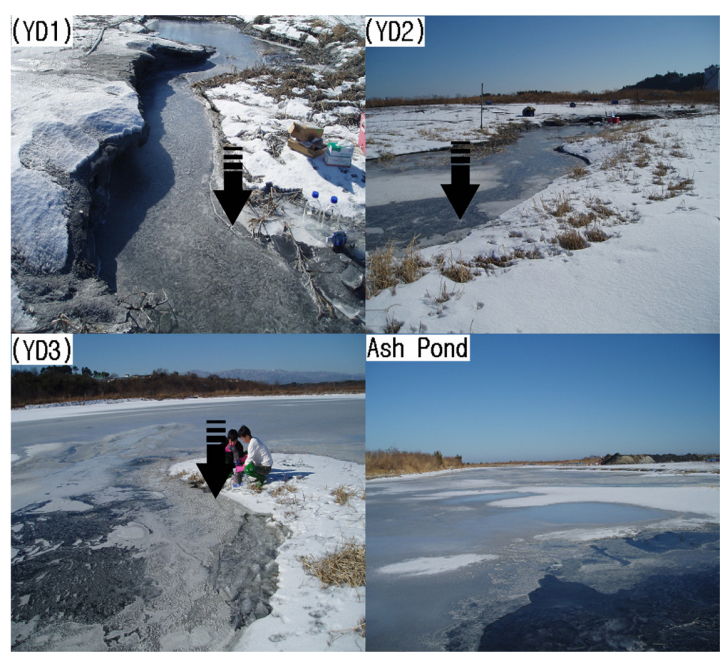

Fig. 2. Photo showing a ash pond at Yeongdong Coal-Fired Power Plant (Arrow: sampling site).

samples at each site innoculated with glucose $(5 \mathrm{mM})$ to stimulate the microbial activity. And the last sample at each site was kept in the natural condition. The whole 9 samples closed using a silicon cork to make anaerobic environment in a anaerobic glove box filled with nitrogen. The samples were stored in a incubator at $24.1^{\circ} \mathrm{C}$. Time course experiments from 0 to 60 days were performed to examine microbial effects on mineralogical changes and concentration changes of cations and anions within fly ash slurry obtained from YD Coal-Fired Power Plant.

\section{Analytical methods}

After aqua regia treatment of fly ashes, total content of fly ashes was analyzed in Korea Basic Science Institute (KBSI) at Daejeon, Korea. The major elements of solution in fly ash slurry were analyzed using ICP-AES (OPTIMA 4300 DV, Perkin-Elmer Co., USA). The trace elements were analyzed using ICP-MS (X5, ThermoElemental Co., USA). The cations (Mg, K, Ca, Mn, Fe, $\mathrm{Zn}$ ) of leachate analyzed using ICP-MS (PE SCIEX Elan 6000, USA), and anions ( $\left.\mathrm{Cl}, \mathrm{SO}_{4}, \mathrm{~F}, \mathrm{NO}_{3}\right)$ of leachate were analyzed using IC (ICS-90, Dionex Co., USA) in Center for University-Wide Research Facilities, Chonbuk National University. The concentration of $\mathrm{HCO}_{3}{ }^{-}$and alkalinity was determined through $\mathrm{HCl}$ titration. The quality control of the analytical data of the samples was carried under adding duplicate sample, reference sample, and blank sample during analytical process. Mineralogical characterization was carried out using X-Ray Diffraction (Dmax 2400, Rigaku Co., Japan) and scanning electron microscopy (SEM) with energy dispersive X-ray (EDX) analyzer (S-4700, Hitachi Co., Japan) in KBSI at Kwangju, Korea.

\section{Chemistry and Mineralogy of Fly Ashes}

\section{Ash pond}

In each sampling site of YD Coal-Fired Power Plant, dissolved oxygen (DO) of seawater was ranged from 35.3 to $71.3 \mathrm{mg} / \mathrm{L}$, water temperature was ranged from 1.1 to $2.6^{\circ} \mathrm{C}$, and $\mathrm{pH}$ was ranged from 6.3 to 8.5 (Table 1). The $\mathrm{pH}$ of Yeongdong was lower relatively than that of ash pond in Dangjin Coal-Fired Power Plant. The $\mathrm{pH}$ of fly ash pond was ranged from 8.87 to 9.06 in Dangin (Cho et al., 2007). This is because the inflow of fly ash and cooling water is little and the desalination of seawater progressed for a long time at the ash pond.

Table 1. General properties of fly ash pond water in YD Coal-Fired Power Plant (YD's water was sampled in January, 2006)

\begin{tabular}{cccc}
\hline \hline Site & DO $(\mathrm{mg} / \mathrm{L})$ & $\mathrm{pH}$ & Temp. $\left({ }^{\circ} \mathrm{C}\right)$ \\
\hline YD1 & 35.3 & 6.3 & 1.1 \\
YD2 & 60.6 & 8.5 & 2.6 \\
YD3 & 71.3 & 6.7 & 1.1 \\
\hline
\end{tabular}


Table 2. Average concentrations of carbon, hydrogen, nitrogen, oxygen, sulfur, and ash of the coal used in Yeongdong CoalFired Power Plant before combustion

\begin{tabular}{cccccccc}
\hline \hline Component & $\mathrm{C}$ & $\mathrm{H}$ & $\mathrm{N}$ & $\mathrm{O}$ & $\mathrm{S}$ & Ash \\
\hline Contents & 61.7 & 1.3 & 0.4 & 1.6 & 0.5 & 34.6 \\
\hline
\end{tabular}

by Korea South-East Power co., Ltd., 2004

\section{Fly ashes}

Domestic anthracite coal is mainly used as a fuel to produce electricity in Yeongdong Coal-Fired Power Plant. The carbon, sulfur, and ash contents of coal were determined 61.7, 0.5, and $34.6 \mathrm{wt.} \%$, respectively. The generation of fly ashes were determined by ash content of coal (Cho et al., 2007). The ashes contents is higher in coal than Dangjin Coal-Fired power station (Cho et al., 2007). The ashes content were showed 11.8 wt.\% in Dangjin. Because of large volume ash in YD Coal-Fired
Power Plant, it may assume that a large amount of fly ash released.

Table 3 shows major elements of weathered fly ash (WFA) and electrostatic precipitator ash (EPA) of Yeongdong Coal-Fired Power Plant. Most fly ashes are composed primarily of $\mathrm{Si}$ and $\mathrm{Al}$ with lesser amounts of $\mathrm{Ca}, \mathrm{Fe}, \mathrm{Na}, \mathrm{Mg}, \mathrm{K}$ and $\mathrm{Ti}$ (Hulett and Weinberger, 1980). The contents of silica dioxide $\left(\mathrm{SiO}_{2}\right)$ and aluminium oxide $\left(\mathrm{Al}_{2} \mathrm{O}_{3}\right)$ in fly ashes are concentrated than those of raw coal (Lee et al., 1997). The contents of silica dioxide

Table 3. Major elements of fly ash in YD Power Plant. YD's fly ash is sampled in January, 2006. (wt.\%)

\begin{tabular}{ccccccccccccc}
\hline \hline Sample & $\mathrm{SiO}_{2}$ & $\mathrm{Al}_{2} \mathrm{O}_{3}$ & $\mathrm{Fe}_{2} \mathrm{O}_{3}{ }^{1)}$ & $\mathrm{MgO}$ & $\mathrm{CaO}$ & $\mathrm{Na}_{2} \mathrm{O}$ & $\mathrm{K}_{2} \mathrm{O}$ & $\mathrm{TiO}_{2}$ & $\mathrm{P}_{2} \mathrm{O}_{5}$ & $\mathrm{MnO}$ & $\mathrm{Total}$ \\
\hline $\mathrm{YD} 1$ & 88.0 & 5.7 & 1.6 & 0.1 & 0.1 & 0.1 & 1.9 & 1.0 & $\mathrm{BD}^{2)}$ & $\mathrm{BD}$ & 98.5 \\
$\mathrm{YD} 2$ & 88.5 & 6.2 & 0.5 & 0.2 & 0.4 & 0.1 & 2.4 & 1.2 & 0.1 & $\mathrm{BD}$ & 99.5 \\
$\mathrm{YD} 3$ & 83.6 & 11.0 & 0.5 & 0.2 & 0.3 & 0.1 & 2.6 & 1.1 & $\mathrm{BD}$ & $\mathrm{BD}$ & 99.5 \\
$\mathrm{YFA}^{3)}$ & 75.1 & 13.2 & 3.3 & 0.2 & 0.4 & 0.1 & 3.0 & 1.5 & 0.1 & $\mathrm{BD}$ & 97.9 \\
\hline
\end{tabular}

$\mathrm{Fe}_{2} \mathrm{O}_{3}{ }^{1)}$ : total content $\mathrm{Fe}, \mathrm{BD}^{2)}$ : Below detection limits, $\mathrm{YFA}^{3)}$ : fly ash sampled at the fly ash silo of the YD Coal-Fired Power Plant.

Table 4. Concentrations of major (wt. \%) and trace ( $\mathrm{mg} \mathrm{kg}^{-1}$ solid) elements in fly ash produced from YD Coal-Fired Power Plant[(Utility Waste*: major elements (Mattigod et al., 1990), trace elements (Eary et al., 1990)]

\begin{tabular}{ccccccc}
\hline \hline \multirow{2}{*}{ Component } & \multicolumn{2}{c}{ YD power plant } & \multicolumn{3}{c}{ Utility waste* } \\
\cline { 2 - 7 } & YD1 & YD2 & YD3 & Y-EPA & Fly ash & Soils \\
\hline $\mathrm{Al}$ & 3.04 & 3.30 & 5.82 & 7.00 & $0.10-20.85$ & $1.00-30.00$ \\
$\mathrm{Ca}$ & 0.07 & 0.27 & 0.18 & 0.30 & $0.11-22.30$ & $0.70-50.00$ \\
$\mathrm{Fe}$ & 1.14 & 0.36 & 0.36 & 2.31 & $1.00-27.56$ & $0.70-55.00$ \\
$\mathrm{Mg}$ & 0.05 & 0.09 & 0.11 & 0.13 & $0.04-7.72$ & $0.06-0.60$ \\
$\mathrm{~K}$ & 1.60 & 1.97 & 2.17 & 2.50 & $0.17-6.72$ & $0.04-3.50$ \\
$\mathrm{Na}$ & 0.05 & 0.06 & 0.10 & 0.08 & $0.01-7.10$ & $0.075-1.00$ \\
$\mathrm{~S}$ & 0.07 & 0.10 & 0.10 & 0.03 & $0.04-6.44$ & $0.003-1.00$ \\
$\mathrm{As}$ & 0.2 & 2.5 & 4.7 & 11.8 & $2-440$ & $1-50$ \\
$\mathrm{Ba}$ & 265.0 & 436.0 & 458.0 & 418.0 & $1-13800$ & $100-3000$ \\
$\mathrm{Cd}$ & 0.2 & 0.3 & 0.4 & 0.6 & $0.1-130$ & $0.1-0.7$ \\
$\mathrm{Cu}$ & 25.3 & 33.6 & 58.7 & 61.4 & $33-2200$ & $2-100$ \\
$\mathrm{~Pb}$ & 14.1 & 25.9 & 43.2 & 62.9 & $3-2100$ & $2-200$ \\
$\mathrm{Mn}$ & 73.1 & 169.4 & 178.5 & 195.8 & $25-3000$ & $20-3000$ \\
$\mathrm{Mo}$ & 1.8 & 2.8 & 1.7 & 8.1 & $1-140$ & $0.2-5$ \\
$\mathrm{Ni}$ & 13.4 & 17.0 & 24.1 & 30.1 & $2-4300$ & $5-500$ \\
$\mathrm{Sr}$ & 48.4 & 137.4 & 126.3 & 95.1 & $30-7600$ & $50-1000$ \\
$\mathrm{~V}$ & 86.5 & 104.8 & 105.9 & 143.4 & $12-1180$ & $20-500$ \\
$\mathrm{Zn}$ & 40.4 & 76.1 & 81.1 & 171.3 & $14-3500$ & $10-300$ \\
\hline
\end{tabular}


of WFA was ranged from 83.6 to $88.5 \mathrm{wt} . \%$ and the that of EPA showed 75.1 wt.\% in YD Coal-Fired Power Plant. The contents of aluminium oxide $\left(\mathrm{Al}_{2} \mathrm{O}_{3}\right)$ of WFA was ranged from 5.7 to $11.0 \mathrm{wt} \% \%$ and the that of EPA showed 13.2 wt.\%. The content of $\mathrm{SiO}_{2}$ and $\mathrm{Al}_{2} \mathrm{O}_{3}$ was higher in YD Coal-Fired Power Plant than Yeongwol Coal-Fired Power Plant. The contents of $\mathrm{SiO}_{2}$ and $\mathrm{Al}_{2} \mathrm{O}_{3}$ showed 69.7 wt.\% in Yeongwol Coal-Fired Power Plant (Lee et al., 1997). Although, these are used for domestic anthracite, it is believe these differences are related to the content of coal.

Table 4 is showed concentrations of major and trace elements in fly ash produced from YD Coal-Fired Power Plant and the contents in utility range of fly ash suggested by Mattigod et al. (1990) and Eary et al. (1990). The most major elements of fly ash exhausted by YD CoalFired Power Plant showed the content in utility range of fly ash and soils suggested by Mattigod et al. (1990). However, the concentration of $\mathrm{Ca}, \mathrm{Fe}$ and $\mathrm{S}$ were lower than utility range of fly ash in some samples. The concentration of $\mathrm{Ca}$ is showed $0.07 \mathrm{wt} . \%$ in YD1, Fe are showed 0.36 wt.\% in YD2 and YD3, and S is showed 0.03 wt. $\%$ in EPA. And the concentration of most trace elements showed content within utility range of fly ash and soils suggested by Eary et al. (1990). While the concentration of $\mathrm{As}$ and $\mathrm{Cu}$ showed $0.2 \mathrm{mg} / \mathrm{kg}$ and $25.3 \mathrm{mg} / \mathrm{kg}$ in YD1, these were lower than utility range of fly ash, concentration of Mo of EPA is higher than utility range of soils suggested by Eary et al. (1990).

\section{Results and Discussion}

\section{Mineralogical characteristics}

Analyses of fly ash using XRD and SEM showed these were contained mainly amorphous phases and crystalline minerals such as quartz $\left(\mathrm{SiO}_{2}\right)$ and mullite $\left(\mathrm{Al}_{6} \mathrm{Si}_{3} \mathrm{Ol}_{15}\right)$. And fly ashes were composed of spherical materials with the size of $0.5-100 \mu \mathrm{m}$. SEM-EDX analysis represents major element of the fly ashes were mainly Si and Al. Also the fly ashes were consisted with $\mathrm{K}, \mathrm{Ca}$ and $\mathrm{S}$.

$\mathrm{XRD}$ and SEM-EDX analyses showed there is no mineralogical changes for 60 days of experiments. But,

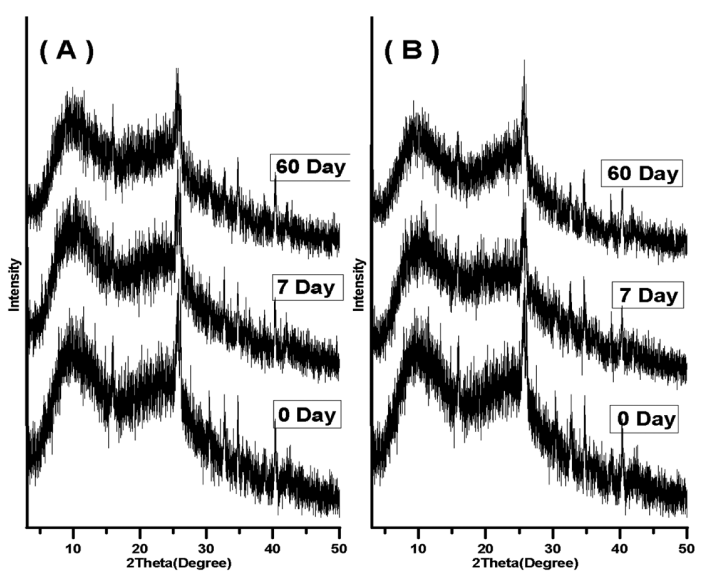

Fig. 3. X-ray diffraction analysis of YD fly ash slurry during the time course experiments for 60 days: autoclaved (A), glucose innoculated (B).

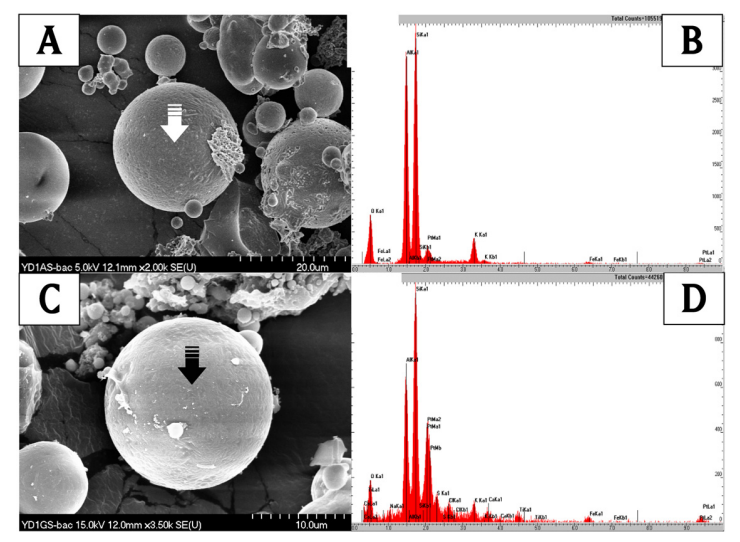

Fig. 4. SEM-EDX analysis of YD fly ash slurry during the time course experiments for 60 days: autoclaved (A, B), glucose innoculated (C, D).

$\mathrm{Mg}, \mathrm{Ca}$, and Fe were enriched in solution during the time course experiments when glucose added to stimulate microbial activity. It may be attributed to microbial leaching of these elements from the fly ashes during the time course experiments.

\section{Geochemical characteristics}

Alkalinity: Alkalinity changes in glucose added samples showed a different trend to autoclaved and natural samples during the time course experiments. Autoclaved and natural samples showed little changes in a alkalinity during the time course experiments. However, glucose added samples showed the sharply 


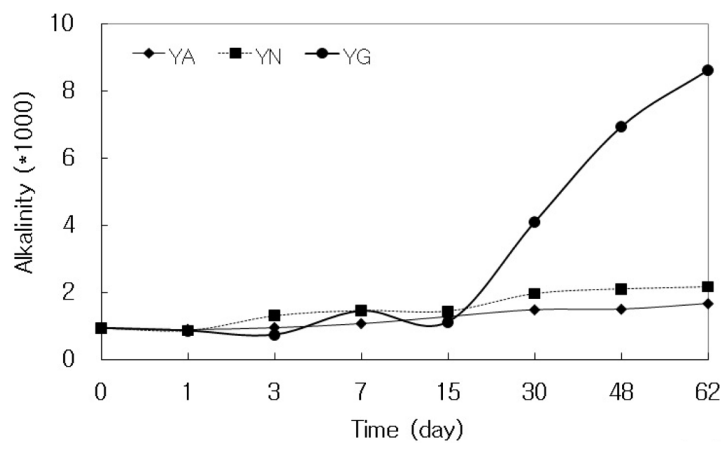

Fig. 5. Alkalinity changes of the fly ash slurry in YD CoalFired Power Plant (YA: autoclaved, YN: natural, YG: added in glucose) during the time course experiments, unit in $\mu \mathrm{eq} / \mathrm{L}$.

increase in alkalinity after 15 days (Fig. 4). While alkalinity of glucose added samples showed $1119.1 \mu \mathrm{eq} /$ $\mathrm{L}$ after 15 days, alkalinity increased by $4090.2 \mu \mathrm{eq} / \mathrm{L}$ after 30 days. This is because carbon dioxide is produced in process that bacteria oxidizes glucose to carbon dioxide, and then the carbon dioxide and water reacts together to form carbonic acid. Accordingly, activity of bacteria is activated sharply from 15 days later.

Cations: $\mathrm{Mg}, \mathrm{Ca}$ and $\mathrm{K}$ have similar tendency on concentration changes in slurry solution of glucose added samples. $\mathrm{Mg}, \mathrm{Ca}$ and $\mathrm{K}$ seemed to increase in the beginning, but decreased 15 days later. The concentration of $\mathrm{Mg}$ in fly ash slurry solution expressed $49.1 \mathrm{mg} / \mathrm{L}$ originally, that showed the maximum of $74.1 \mathrm{mg} / \mathrm{L} 15$ days later in glucose added samples. After 15 days, it decreased gradually, it showed the concentration of 42.5 $\mathrm{mg} / \mathrm{L} 60$ days later. The concentration of $\mathrm{Ca}$ in fly ash slurry solution expressed $125.7 \mathrm{mg} / \mathrm{L}$ originally, that showed the maximum of $213.5 \mathrm{mg} / \mathrm{L} 15$ days later in glucose added samples. After 15 days, it decreased gradually, it showed the concentration of $90.2 \mathrm{mg} / \mathrm{L} 60$ days later. $\mathrm{K}$ in glucose added samples expressed 21.3 $\mathrm{mg} / \mathrm{L}$ originally, that showed the maximum of $27.8 \mathrm{mg} / \mathrm{L}$ 15 days later. After 15 days, it decreased gradually, it showed the concentration of $13.1 \mathrm{mg} / \mathrm{L} 60$ days later.

When fly ash comes in contact with seawater in the beginning, the $\mathrm{Mg} \mathrm{Ca}$ and $\mathrm{K}$ concentrations increase because of natural leaching (Hjelmar, 1990; Hockley and Van Der Sloot, 1991). However, if fly ash comes in contact with seawater for a long time, it decrease through precipitation because of the increase of $\mathrm{pH}$ by calcium oxide in fly ash (Roethel and Oakley, 1985; Hockley and Van Der Sloot, 1991). Comparing with previous studies for Dangjin Coal-Fired Power Plant (Cho et al., 2007), while YD Coal-Fired Power Plant recycled fly ash, fly ashes in Dangjin Coal-Fired Power Plant was discharged into the ash pond continuously. Therefore, the chemical changes happens actively in ash pond of Dangjin compared with YD Coal-Fired Power Plant. And the concentration changes of $\mathrm{Mg}, \mathrm{Ca}$ and $\mathrm{K}$ show much more changes in the samples of Dangjin than YD CoalFired Power Plant. It is think that content of iron (III) oxide, magnesium oxide, and calcium oxide is lower than Dangjin's fly ash.

However, $\mathrm{Mg}$ and $\mathrm{Ca}$ have a little different tendency on concentration changes in slurry solution of glucose added samples. The concentration of $\mathrm{Mg}$ and $\mathrm{Ca}$ in glucose add sample showed the maximum of $74.1 \mathrm{mg} / \mathrm{L}$ and $190.5 \mathrm{mg} / \mathrm{L}$ after 15 days, and then, it was decreased 42.5 and $90.2 \mathrm{mg} / \mathrm{L}$ after 60 days. Both $\mathrm{Mg}$ and Ca were more decreased by 31.6 and $123.3 \mathrm{mg} / \mathrm{L}$ than maximum concentration. The biogeochemical processes facilitated calcite and siderite precipitation (Roh et al., 2003a). So, this is because carbon dioxide produced in process that bacteria consume glucose, reacts with metal ion such as $\mathrm{Fe}, \mathrm{Mg}$ and $\mathrm{Ca}$ to form carbonate mineral and this minerals are precipitated (Konhauser, 1998; Roh et al., 2003a). The biogeochemical processes to precipitate carbonate minerals were effective carbon dioxide sequestration (Roh et al., 2003a).

$\mathrm{Fe}$ and $\mathrm{Mn}$ had a little different tendency on concentration changes in slurry solution of glucose added samples. In beginning, Fe shows the concentration below the detection limit in the samples. But, it was sudden detected 15 days later in the glucose added samples. And it showed maximum concentration of $6.8 \mathrm{mg} / \mathrm{L} 60$ days later. Fe-containing minerals in the aquifer would begin to decompose, releasing ions like $\mathrm{Fe}^{3+}$ to solution. If the amount of dissolved oxygen is limited, $\mathrm{Fe}^{3+}$ are reduced into $\mathrm{Fe}^{2+}$ by bacteria. And there, they were detected suddenly because $\mathrm{Fe}^{2+}$ are dissolved more easily than $\mathrm{Fe}^{3+}$. If bicarbonate is produced in process that bacteria 

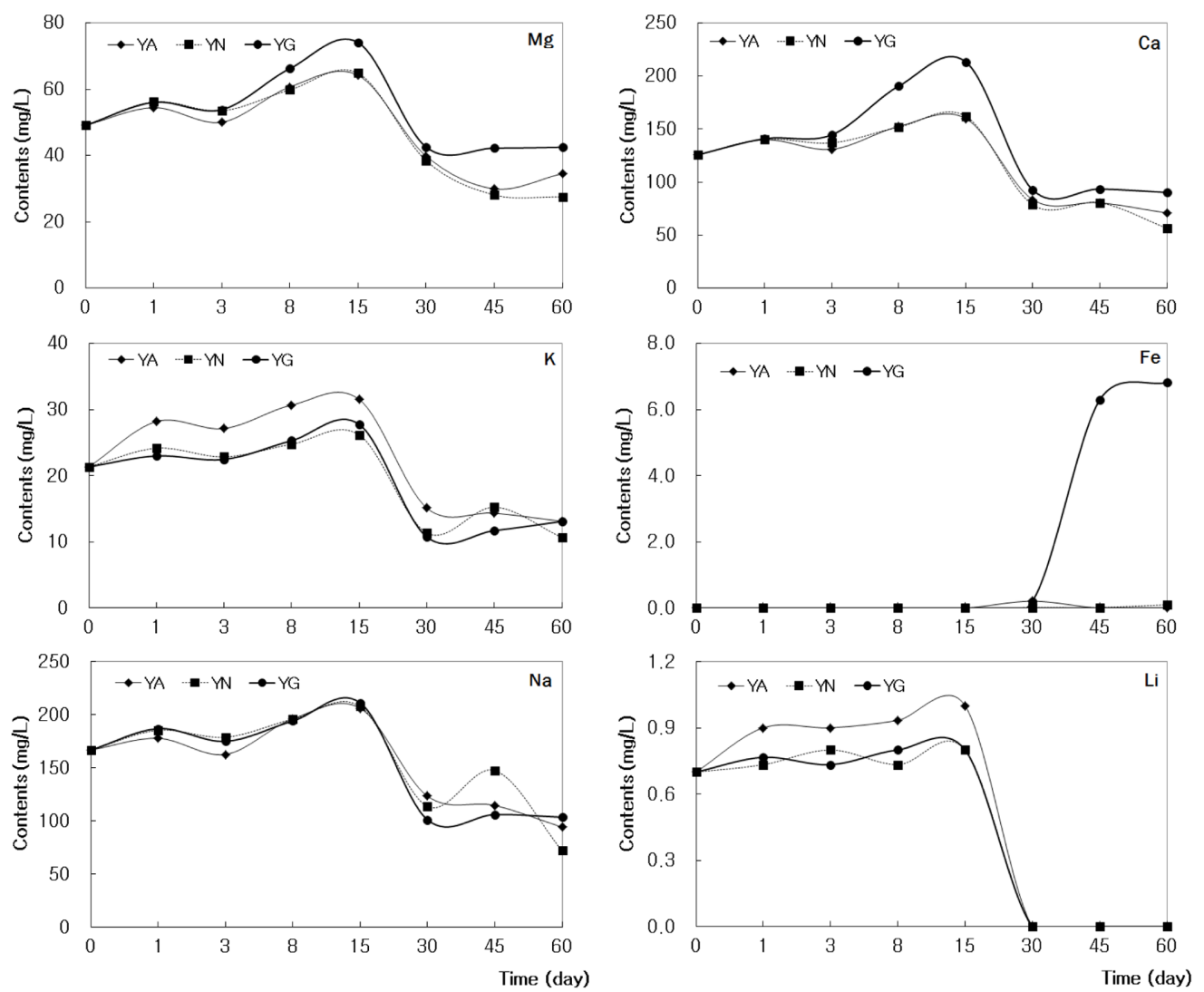

Fig. 6. Changes of cations concentrations in fly ash slurry during the time course experiments.

consume glucose, $\mathrm{Fe}^{2+}$ react with bicarbonate to form carbonate minerals such as siderite. Because that carbonate minerals are precipitated, it is not detected again (Konhauser, 1998; Roh et al., 2003a). Geochemical data showed that the bacteria not only immobilize metals from the ash pond by facilitating the chemical reaction(ex: Eh and $\mathrm{pH}$ ) with $\mathrm{Mn}$ and Fe but may also play an important role in sequestration of carbon dioxide by carbonate mineral precipitation (Roh et al., 2003a). However, Mn showed the concentration below the detection limit in the all samples during the time course experiments.

$\mathrm{Na}$ and $\mathrm{Li}$ of concentration variation trend was similar to that of $\mathrm{Mg}$ and $\mathrm{Ca}$. $\mathrm{Na}$ and $\mathrm{Li}$ seemed to increase in the beginning, but these showed decrease 15 days later. The concentration of $\mathrm{Na}$ in fly ash slurry solution showed $166.5 \mathrm{mg} / \mathrm{L}$ originally, that showed the maximum of $211.0 \mathrm{mg} / \mathrm{L} 15$ days later in glucose added samples. It decreased gradually after 15 days, it showed the concentration of $103.3 \mathrm{mg} / \mathrm{L} \quad 60$ days later. The concentration of $\mathrm{Li}$ in fly ash slurry solution showed 0.7 $\mathrm{mg} / \mathrm{L}$ originally, that showed the maximum of $1.0 \mathrm{mg} / \mathrm{L}$ 15 days later in autoclaved samples. It showed the concentration below the detection limit after 15 days.

Anions: $\mathrm{Cl}^{-}$is one of the harmful element and may cause environmental problems during coal combustion (Vassilev et al., 2000). Since the concentration of $\mathrm{Cl}^{-}$in waste waters which transport fly ash from power plant exceed significantly the respective Clarke values for surface water, it may contaminate the surface and subsoil water, soils and plants in the areas near power plant (Vassilev and Vassileva, 1997). The concentration of $\mathrm{Cl}^{-}$ in slurry solution was ranged from $246.9 \mathrm{mg} / \mathrm{L}$ to 323.8 $\mathrm{mg} / \mathrm{L}$ during the time course experiments. It is think that the high concentration of $\mathrm{Cl}^{-}$was induced seawater. 

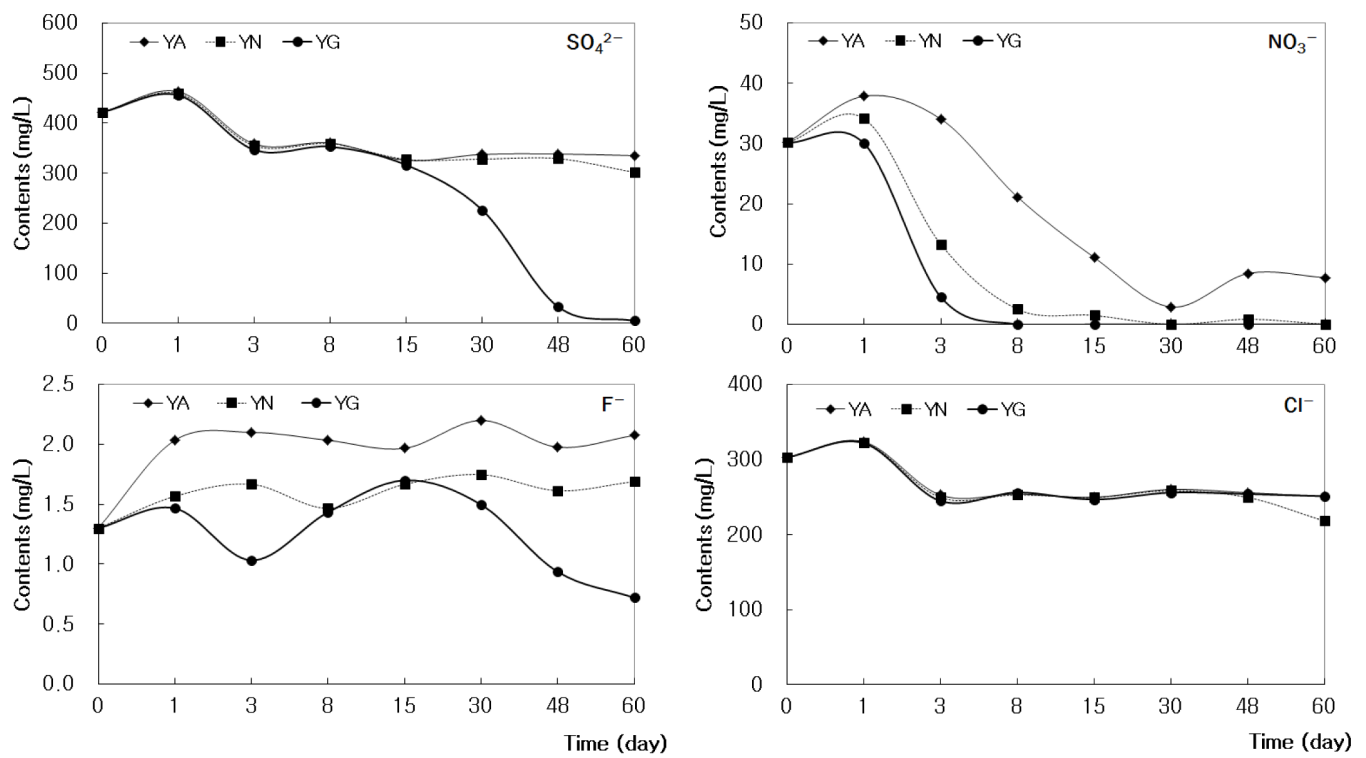

Fig. 7. Changes of anions concentrations in fly ash slurry during the time course experiments.

However, because amount of waste waters which transport fly ash from power plant is less, and seawater was already proceeded fairly desalination in the ash pond, the concentration of $\mathrm{Cl}^{-}$was lower relatively than Dangjin Coal-Fired Power Plant ash pond (Cho et al., 2007).

The concentration of $\mathrm{SO}_{4}^{2-}$ decreased in all samples during the time course experiments. Especially, Comparing with the autoclaved and natural samples, it seemed to decrease even more in slurry solution of glucose added samples. The concentration of $\mathrm{SO}_{4}{ }^{2-}$ in the autoclaved samples showed $422.2 \mathrm{mg} / \mathrm{L}$ originally, this decreased by 87.0 to $335.2 \mathrm{mg} / \mathrm{L}$ over the 60 days. On the other hand, it decreased sharply since 1 days (456.2 $\mathrm{mg} / \mathrm{L}$ ) in the glucose added samples and finally decreased by 417.0 to $5.2 \mathrm{mg} / \mathrm{L}$ over 60 days. During the time course experiments, the $\mathrm{SO}_{4}{ }^{2-}$ concentration of glucose added samples changed much more difference of content as $78.2 \%$ than that of autoclaved samples. The concentration changes of $\mathrm{SO}_{4}{ }^{2-}$ is think that the action of sulphate-reducing bacteria is induced depletion of sulphide production such as pyrite (Bottrell and Morton, 1992). Carbon dioxide is produced in process that sulphate-reducing bacteria consume glucose, and bacteria obtains electrons by these processes. The obtained electrons reduce sulfate ions to form sulfur ion gradually. In turn, the sulfur ion combines with hydrogen ion or metal ion to form sulfide minerals like HS, MnS, FeS (Tributsch, 2001). Iron or sulphate-reducing bacteria use $\mathrm{SO}_{4}{ }^{2-}$ in a process that they consume glucose in reducing environment, and they play a role of decreasing $\mathrm{Mn}$ and $\mathrm{Fe}$ ions.

$\mathrm{NO}_{3}^{-}$is similar to $\mathrm{SO}_{4}^{2-}$ on tendency of concentration changes. In natural samples, $\mathrm{NO}_{3}^{-}$showed $30.1 \mathrm{mg} / \mathrm{L}$ originally. It decreased gradually since first day and decreased to $7.8 \mathrm{mg} / \mathrm{L}$ in 60 days. On the other hand, it decreased continuously and showed under the detection limits in 8 days in glucose added samples. In a natural environments, $\mathrm{NO}_{3}{ }^{-}$and $\mathrm{NO}_{2}{ }^{-}$are apt to be soluble in water except for an environment which is very low in $\mathrm{pH}$ (Nelson, 2004). However if the reducing environment is made, $\mathrm{NO}_{3}{ }^{-}$is reduced into $\mathrm{N}_{2} \mathrm{O}$ and $\mathrm{CO}_{2}$ by bacteria (Stumn and Morgan, 1996). Therefore, it is believed that the concentration of $\mathrm{NO}_{3}^{-}$decrease rapidly in glucose added samples compared with other samples.

$\mathrm{F}^{-}$was no quite difference on tendency of concentration changes according to the treatment method of samples. It showed only the concentration change of $0.4-0.8 \mathrm{mg} / \mathrm{L}$. 


\section{Conclusions}

It was known that not only physicochemical factors and microbial activities play an important role in reaction between subsurface media and fly ash. So, the objective of this research was to study how indigenous bacteria affect heavy metal leaching and mineralogy in fly ash slurry during the fly ash-seawater interactions in the ash pond located in Yeongdong seashore, Korea.

\section{And the results were}

1. In Yeongdong Coal-Fired Power Plant ash pond, dissolved oxygen was ranged from 35.3 to $71.3 \mathrm{mg} / \mathrm{L}$, water temperature was ranged from 1.1 to 2.6 and $\mathrm{pH}$ was ranged from 6.3 to 8.5. Except for some elements (Ca of YD1, Fe of YD2 and YD3, S of Yeongdong EPA), elements included in WFA and EPA showed the concentration within utility range of fly ash suggested by Mattigod et al. (1990).

2. EPA and WFA of YD Coal-Fired Power Plant showed that they contain mainly amorphous phases and crystalline minerals such as quartz $\left(\mathrm{SiO}_{2}\right)$ and mullite $\left(\mathrm{Al}_{6} \mathrm{Si}_{3} \mathrm{O} 1_{15}\right)$. For the EPA and WFA of Yeongdong CoalFired Power Plant, fly ashes were composed of spherical materials with the size of 0.5-100 $\mu \mathrm{m}$. Most fly ahes are composed of $\mathrm{Si}$ and $\mathrm{Al}$. The result of XRD and SEMEDX analysis showed no mineralogical changes for 60 days of experiments. But, $\mathrm{Mg}, \mathrm{Ca}$ and Fe were enriched in solution during the time course experiments when glucose added to stimulated microbial activity. It may be attributed to microbial leaching of these elements from the fly ashes during the time course experiments.

3. The concentration of $\mathrm{Mg}$, and $\mathrm{Ca}$ seemed to decrease during the time course experiments. Especially, Comparing with the autoclaved and natural samples, $\mathrm{Mg}$, $\mathrm{Ca}$, and $\mathrm{Fe}$ had a little different tendency on concentration changes in slurry of glucose added samples. This is because carbon dioxide produced in process that bacteria consume glucose, reacts with metal ion such as Fe and $\mathrm{Ca}$ to form carbonate mineral and this minerals are precipitated. Geochemical data showed that the bacteria not only immobilize metals from the ash pond by facilitating the chemical reaction but may also play an important role in sequestration of carbon dioxide by carbonate mineral precipitation.

4. The concentration of $\mathrm{SO}_{4}{ }^{2-}$ decreased in samples during the time course experiments. Especially, comparing with the autoclaved and natural samples, it seems to decrease even more in slurry of glucose added samples. This is because iron or sulphate-reducing bacteria reduce sulfate ions to form sulfur ion gradually, in turn, the sulfur ion combine with hydrogen ion or metal ion to form sulfide minerals like $\mathrm{HS}, \mathrm{MnS}, \mathrm{FeS}$. Iron or sulfur reducing bacteria use $\mathrm{SO}_{4}{ }^{2-}$ in a process that they consume glucose in reducing environment, and they play a role of decreasing $\mathrm{Mn}$ and Fe ions.

Under the microbial activated environment, microbes can not only participate in chemical reactions in natural environment but also facilitate the formation of hazardous elements(ex: fluorine $>3 \mathrm{mg} / \mathrm{L}$ ). And the recycling ratio of fly ash is increasing in Korea. So we need to a little more investigate for the species of indigenous microbes related with the reaction between fly ash and seawater as well as the information about mineralogical phase transformation.

This study was investigated biogeochemical change of fly ashes during the time course experiments. The activity of bacteria was related to both the increase of alkalinity concentration and the decrease of sulphate ion concentration. Although, this study failed to find out the kind of indigenous microbes, it may be used understanding of characteristic of bacteria in fly ash pond.

\section{Acknowledgments}

I would like to thank professor Kim, J.B. from Sunchon National University, Roh, Y. from Chonnam National University, and an anonymous reviewer for their critical comments.

\section{References}

Bottrell, S.H. and Morton, M.D.B., 1992, A reinterpretation of the genesis of the Cae Coch pyrite deposit, North Wales. Journal of the Geological Society, London, UK, 149, 581-584. 
Cho, K.S., Roh, Y., and Chung, D.H., 2007, A Biogeochemical study on the heavy metal leaching from coal fly ash disposed by Dangjin fire plant in the coastal environment. Journal of Korean Earth Society, 28, 112-122.

Eary, L.E., Dhanpat, Rai, Mattigod, S.V., and Ainsworty, C.C., 1990, Geochemical factors controlling the mobilization of inorganic constituents from fossil fuel combustion residues. Journal of Environmental Quality, 19, 202-214.

Gay, A.J. and Davis, P.B., 1987, Some environmental aspects of coal fly ash. Coal science and technology, 20, 221-243.

Han, O.H., Chun, H.S., and Yoon, R.H., 2001, Development of a Electrostatic Separation Technology for Removal of Unburned Carbon from Fly Ash. Journal of the Korean Institute of Mineral and Energy Resources Engineers, 38, 416-423.

Hansen, L.D. and Fisher, G.L., 1980, Elemental distribution in coal fly ash particles. Environmental Science and Technology, 14, 1111-1117.

Hjelmar, O., 1990, Leachate from land disposal of coal fly ash. Waste Management and Research, 8, 429-449.

Hockly, D.E. and Van Der Sloot, H.A., 1991, Long-term processes in stabilized coal waste block exposed to sea water. Environmental Science and Technology, 25, 1408-1414.

Hulett, L.D. and Weinberger, A.J., 1980, Some etching studies of the microstructure and composition of large aluminosilicate particles in fly ash from coal-burning power plants. Environmental Science and Technology, 14, 965-970.

Kim, K.J., Yeo, S.G., Yun, S.T., and Hwang, G.S., 2002, Geochemical Study on the Fly Ash-Seawater Reaction. Proceeding of the Annual Joint Conference: Petrological Society of Korea and Mineralogical Society of Korea, 70-73.

Konhauser, K.O., 1998, Diversity of bacterial iron mineralization. Earth Science Review, 43, 91-121.

Lee, G.H., Choi, S.K., Moon, H.S., and Lee, S.H., 1997, Mineralogical and Geochemical Characteristics of PFA(Pulverised Fuel Ash) from Yongwol Power Plant. Economic Environmental Geology, 30, 443-450.

Lee, J.H., Seo, H.N., Kim, C.R., Kim, N.J., and Min, K.S., 2001, Characteristics of OPC-Fly ash-Slag System. Cement Symposium, 28, 47-53.

Mattigod, S.V., Dhanpat, Rai, Eary, L.E., and Ainsworty, C.C., 1990, Geochemical factors controlling the mobilization of inorganic constituents from fossil fuel combus- tion residues: Review of the major elements. Journal of Environmental Quality, 19, 188-201.

Nelson, E.G., 2004, Principles of environmental geochemistry. Tomson Brooks/Cole, USA, 514 p.

Nickson, R.T., McArthur, J.M., Ravenscroft, P., Burgess, W.G., and Ahmed, K.M., 2000, Mechanism of arsenic release to groundwater, Bangladesh and West Bengal. Applied Geochemistry, 15, 403-413.

Reijnders, L., 2005, Disposal, uses and treatments of combustion ashes: A review. Resources, Conservation and Recycling, 43, 313-336.

Roethel, F.J.and Oakley, S.A., 1985, Effects of seawater on the mineralogical and chemical composition of coalwaste blocks. In Duedall, I.W., Kester, D.R., Park, P.K., and Ketchum, B.H. (eds.), Wastes in the Ocean, Vol. 4, Energy Wastes in the Ocean. Wiley, NY, USA, 691704.

Roh, Y., Lauf, R.J., and Phelps, T.J., 2001, Utilization of biomineralization processes with fly ash for carbon sequestration. First National Conference on Carbon Sequestration, Washington, D.C., May, 15-17.

Roh, Y., Moon, J.W., Song, Y., and Moon, H.S., 2003a, Biomineralization processes using fly ash for carborn sequestration. Journal of Mineralogical Society of Korea, 16, 171-180.

Roh, Y., Lauf, R.J., and Phelps, T.J., 2003b, Biogeochemical processes utilizing fly ash for carbon sequestration. Second National Conference on Carbon Sequestration, Washington, D.C., May, 14-17.

Stumn, W. and Morgan, J.J., 1996, Aquatic Chemistry. 3rd ed, John Wileys and Son, NY, USA, 1022 p.

Tributsch, H., 2001, Direct versus indirect bioleaching. Hydrometallurgy, 59, 177-185.

Vassilev, S.V., Eskenazy, G.M., and Vassileva, C.G., 2000, Contents, modes of occurrence and behaviour of chlorine and bromine in combustion wastes from coal-fired Power Plants. Fuel, 79, 923-937.

Vassilev, S.V. and Vassileva, C.G., 1997, Geochemistry of coals, coal ashes and combustion wastes from coal-fired Power Plants. Fuel Process Technology, 51, 19-45.

Yoon, C.H., Oh, K.C., Kim, Y.W., and Shin, B.S., 1995, Content of Heavy Metals in Coal Fly Ash from the Samcheonpo and the Seocheon Power Plant. Economic Environmental Geology, 28, 147-154.

White, C., Sayer, J.A., and Gadd, G.M., 1997, Microbial solubilization and immobilization of toxic metals: Key biogeochemical processes for treatment of contamination. FEMS microbiology reviews, 20, 503-516. 